\title{
Komitmen Kepemimpinan Kepala Sekolah Dalam Mengimplementasi Kebijakan Untuk Meningkatkan Mutu Pendidikan di SMP Negeri 3 Palopo
}

\author{
Kartini \\ SMP Negeri 3 Palopo \\ $+62853-9975-3239$
}

\begin{abstract}
Abstrak
Studi ini menelaah komitmen kepala sekolah dalam mengimplementasi kebijakan untuk meningkatkan mutu pendidikan di SMP Negeri 3 Palopo, Kota Palopo. Tujuan Penelitian ini adalah untuk mengetahui komitmen kepemimpinan kepala sekolah dalam hal perencanaan, pengorganisasian, supervise, dan pengawasan. Penelitian ini merupakan penelitian deskriptif kuantitatif. Populasi penelitian ini adalah keseluruhan guru di SMP Negeri 3 Palopo sebanyak 20 orang guru. Pengumpulan data dengan teknik angket dan dokumentasi kemudian dianalisis dengan rata-rata. Hasil yang diperoleh menunjukkan bahwa komitmen kepemimpinn kepala sekolah mampu terlaksanakan. Hal ini dibuktikan oleh penilaian guru yang cenderung baik. Begitu pula dengan kemampuan pengorganisasian, kemampuan supervise, dan kemampuan pengawasan yang seluruhnya mampu dilaksanakan dengan baik, berdasarkan penilaian guru.
\end{abstract}

Kata Kunci: kepala sekolah, komitmen kebijakan, perencanan, pengawasan, pengorganisasian, supervisi

\section{Pendahuluan}

Setiap organisasi, tidak terkecuali organisasi pendidikan, idealnya harus ada pemimpin yang dipatuhi dan disegani bawahannya dan senantiasa bergulat dengan kebijakan-kebijakan. Organisasi tanpa pemimpin akan kacau arena tidak ada seorang yang memerintah dan mengarahkan bawahan untuk mencapai tujuan organisasi secara efisien dan efektif.

Mutu pendidikan tercapai apabila masukan, proses, keluaran, guru, sarana dan prasarana serta biaya apabila seluruh komponen tersebut memenuhi syarat tertentu. Namun dari beberapa komponen tersebut yang lebih banyak berperan adalah tenaga kependidikan yang bermutu yaitu yang mampu menjawab tantangan-tantangan dengan cepat dan tanggung jawab. Tenaga kependidikan pada masa mendatang akan semakin kompleks, sehingga menuntut tenaga kependidikan untuk senantiasa melakukan berbagai peningkatan dan penyesuaian penguasaan kompetensinya. Pendidikan yang bermutu sangat membutuhkan tenaga kependidikan yang professional.

Tenaga kependidikan mempunyai peran yang sangat strategis dalam pembentukan pengetahuan, ketrampilan, dan karakter peserta didik. Oleh karena itu tenaga kependidikan yang professional akan melaksanakan tugasnya secara professional sehingga menghasilkan tamatan yang lebih bermutu. Menjadi tenaga kependidikan yang profesional tidak akan terwujud begitu saja tanpa adanya upaya untuk meningkatkannya, adapun salah satu cara untuk mewujudkannya adalah dengan pengembangan profesionalisme ini membutuhkan 
dukungan dari pihak yang mempunyai peran penting dalam hal ini adalah kepala sekolah, dimana kepala sekolah merupakan pemimpin pendidikan yang sangat penting karena kepala sekolah berhubungan langsung dengan pelaksanaan program pendidikan di sekolah. Ketercapaian tujuan pendidikan sangat bergantung pada kecakapan dan kebijaksanaan kepemimpinan kepala sekolah yang merupakan salah satu pemimpin pendidikan.

Pimpinan yang baik dalam menjalankan kepemimpinannya merupakan point di mana organisasi ingin meningkatkan dan mengembangkan knowledge dan ability individu. Sesuai dengan kebutuhan masa kini maupun masa datang. Menyadari berbagai hal tersebut dalam pencapaian tujuan pendidikan nasional pada umumnya khususnya pencapaian tujuan pendidikan sesuai dengan Visi Misi di sekolah SMP Negeri 3 Palopo sebagai lembaga pendidikan yang sehat, cerdas dan ihksan maka perlu dikaji peran seorang kepala sekolah sebagai pemimpin dikelolanya.

Tanpa seorang pemimpin sesuatu organisasi tak lain merupakan campur aduk manusia dan peralatan dalam suatu tempat, kepemimpinan merupakan kecakapan untuk mengendalikan, mengatur orang-orang agar berperan sesuai fungsinya masing-masing, kepemimpinan dapat menjadi penyemangat, menjadi motivasi kumpulan orang tadi dalam beraktivitas

Kepemimpinan adalah proses mempengaruhi atau memberi contoh oleh pemimpin kepada pengikutnya dalam upaya mencapai tujuan organisasi. Kepemimpinan sesungguhnya tidak ditentukan oleh pangkat atau pun jabatan seseorang. Kepemimpinan adalah sesuatu yang muncul dari dalam dan merupakan buah dari keputusan seseorang untuk mau menjadi pemimpin, baik bagi dirinya sendiri, bagi keluarganya, bagi lingkungan pekerjaannya, maupun bagi lingkungan sosial dan bahkan bagi negerinya.

Tetapi seiring perkembangan zaman pemimpin tidak lagi ditentukan semata hanya karena keunggulan fisik semata tapi juga keunggulan wawasan, kecerdasan, kompetensi bawahan, kepatuhan atau ketaatan bawahan dalam menjalankan perintah pimpinan, tiap orang memiliki kecerdasan yang berbeda seperti kecerdasan social, kecerdasan managerial, kecerdasan ekonomi, kecerdasan teknologi, apabila seseorang menguasai satu kecerdasan maka ia akan unggul dan itu bias menjadi modal seseorang untuk menjadi pemimpin, sehingga kepemimpinan modern tidak terfokus pada satu keturunan, siapa saja yang memiliki kecerdasan maka dia berpeluang menjadi pemimpin.

\section{Komitmen dan Kepemimpinan Kepala Sekolah}

Setiap organisasi, terutama organisasi nonprofit seperti organisasi kependidikan, memerlukan komitmen dari para anggotanya. Komitmen dalam artian ini, menurut Shaw, Delery \& Abdulla (2003: 2), adalah hasil dari investasi atau kontribusi terhadap organisasi, atau suatu pendekatan psikologis yang menggambarkan suatu hal yang positif, keterlibatan yang tinggi, orientasi intensitas tinggi terhadap organisasi; atau dalam pandangan Benkhoff (1997: 3) sebagai derajat kepedulian karyawan dan kontribusinya terhadap keberhasilan organisasi.

Kompetensi kepemimpinan belum tentu dapat menjamin keberhasilan seorang pemimpin dalam mengimplementasikan kebijakan. Kompetensi tidak akan memberikan atau menyumbangkan apapun jika tidak dilakukan atau diaplikasikan. Jadi kompetensi membutuhkan motor penggerak agar bekerja sehingga dapat menyumbangkan sesuatu. Motor penggeraknya adalah komitmen. Tepatnya adalah komitmen seorang pemimpin terhadap organisasi, atau yang lazim disebut komitmen organisasi. Sebagaimana dikatakan Luthans (2010: 147) bahwa komitmen organisasi merupakan suatu hasrat yang kuat untuk tetap menjadi anggota organisasi; suatu keinginan untuk menunjukkan usaha tingkat tinggi atas 
nama organisasi; dan keyakinan yang kuat dalam menerima nilai-nilai dan tujuan-tujuan organisasi.

Jadi, selain memiliki kompetensi, seorang pemimpin juga harus memiliki komitmen pada organisasi yang dipimpin. Komitmen yang di dalamnya terdapat tiga gatra: hasrat kuat tetap menjadi anggota organisasi, keinginan menunjukkan usaha tingkat tinggi atas nama organisasi, dan keyakinan kuat dalam menerima nilai-nilai serta memperjuangkan tujuan organisasi, akan mendorong bekerjanya kompetensi-kompetensi yang dimiliki oleh seorang pemimpin untuk didekasikan kepada organisasi. Dalam perspektif ini, maka pemimpim yang memiliki komitmen tinggi akan cenderung mendedikasikan semua kompetensinya untuk mengimplementasikan semua kebijakan organisasi, baik yang datang dari internal organisasi maupun dari luar organisasi.

\section{Fungsi Kepemimpinan Sebagai Manajer Pendidikan}

Agar desentralisasi dan otonomi pendidikan berhasil dengan baik, kepemimpinan kepala sekolah perlu diberdayakan. Pemberdayaan berarti peningkatan kemampuan secara fungsional, sehingga kepala sekolah mampu berperan sesuai dengan tugas, wewenang, dan tanggung jawabnya. Kepala sekolah harus bertindak sebagai manajer dan pemimpin yang efektif. Sebagai manajer ia harus mampu mengatur agar semua potensi sekolah dapat berfungsi secara optimal. Hal ini dapat dilakukan jika kepala sekolah mampu melakukan fungsifungsi manajemen dengan baik, meliputi (1) perencanaan; (2) pengorganisasian; (3) pengarahan; dan (4) pengawasan.

Dari segi kepemimpinan, seorang kepala sekolah mungkin perlu mengadopsi gaya kepemimpinan transformasional, agar semua potensi yang ada di sekolah dapat berfungsi secara optimal. Kepemimpinan transformasional dapat didefinisikan sebagai gaya kepemimpinan yang mengutamakan pemberian kesempatan, dan atau mendorong semua unsur yang ada dalam sekolah untuk bekerja atas dasar sistem nilai (values system) yang luhur, sehingga semua unsur yang ada di sekolah (guru, siswa, pegawai, orangtua siswa, masyarakat, dan sebagainya) bersedia, tanpa paksaan, berpartisipasi secara optimal dalam mencapai tujuan ideal sekolah.

Ciri seorang yang telah berhasil menerapkan gaya kepemimpinan transformasional (Luthans, 1995: 358) adalah sebagai berikut: (1) mengidentifikasi dirinya sebagai agen perubahan (pembaruan); (2) memiliki sifat pemberani; (3) mempercayai orang lain; (4) bertindak atas dasar sistem nilai (bukan atas dasar kepentingan individu, atau atas dasar kepentingan dan desakan kroninya); (5) meningkatkan kemampuannya secara terus-menerus; (6) memiliki kemampuan untuk menghadapi situasi yang rumit, tidak jelas, dan tidak menentu; serta (7) memiliki visi ke depan.

Dalam era desentralisasi, kepala sekolah tidak layak lagi untuk takut mengambil inisiatif dalam memimpin sekolahnya. Pengalaman kepemimpinan yang bersifat top down seharusnya segera ditinggalkan. Pengalaman kepemimpinan kepala sekolah yang bersifat instruktif dan top down memang telah lama dipraktikkan di sebagian besar sekolah kita ketika era sentralistik masih berlangsung.

Beberapa fenomena pendidikan persekolahan sebagai hasil dari model kepemimpinan yang instruktif dan top down dapat kita sebutkan, antara lain, sistem target pencapaian kurikulum, target jumlah kelulusan, formula kelulusan siswa, dan adanya desain suatu proyek peningkatan kualitas sekolah yang harus dikaitkan dengan peningkatan NEM (nilai ebtanas murni-Red) secara instruktif. Keadaan ini berakibat pada terbelenggunya seorang kepala sekolah dengan 
juklak dan juknis. Dampak negatifnya ialah tertutupnya sekolah pada proses pembaruan dan inovasi.

Keadaan ini pernah dialami oleh penulis ketika harus melakukan diseminasi classroom action research di sekolah-sekolah. Kepala sekolah yang mengadopsi kepemimpinan instruksiotoritarian tidak selalu bisa memberi peluang kepada penulis untuk mengajak para guru melakukan classroom action research di kelasnya, dengan alasan kegiatan penelitian kelas itu akan mengganggu pencapaian target kurikulum yang telah dicanangkan oleh pusat.

Kepemimpinan merupakan kekuatan aspirasional, kekuatan semangat dan kekuatan moral yang kreatif yang mampu mempengaruhi para anggotanya untuk mengubah sikap sehingga mereka menjadi konform dengan keinginan pemimpin. Untuk itu, komitmen seseorang didalam memimpin akan amat berpengaruh terhadap organisasi yang dipimpinnya. Baik pengaruh positif maupun pengaruh negatif didalam organisasi tersebut. Berdasarkan latar belakang yang telah diuraikan di atas, maka rumusan masalah dalam penelitian ini adalah:

1. Bagaimana komitmen seorang pemimpin dalam memimpin lembaga yang dipimpinnya agar dapat meningkatkatkan mutu pendidikan di SMP Negeri 3 Palopo?

2. Bagaimana komitmen seorang pemimpin dalam menjawab indikator komitmen kepemimpinannya di SMP Negeri 3 Palopo bisa berjalan dengan baik.

\section{Metode Penelitian}

Fokus penelitian ini adalah komitmen kepemimpinan kepala sekolah dalam mengembangkan sekolah efektif. Sasaran yang akan diteliti adalah komitmen kepala sekolah sebagai pemimpin dan pengelola sekolah. Oleh karena itu, pendekatan yang dianggap cocok digunakan dalam penelitian ini adalah pendekatan deskriptif kuantitatif.

Desain penelitian adalah penelitian deskriptif yang digunakan oleh peneliti untuk memudahkan dalam mengkaji permasalahan yang telah dirangkum berkaitan dengan permasalahan yang diteliti. Penelitian deskriptif dirancang untuk memperoleh data dan informasi tentang gejala populasi. Berdasarkan prinsip penelitian deskriptif, maka penelitian ini mengumpulkan data, mengolah data, dan menganalisisnya kemudian menyajikan hasil penelitian secara objektif.

\section{Sumber dan Teknik Pengumpulan Data}

Subyek dalam dalam penelitian ini yang menjadi responden berjumlah 20 orang yang merupakan unsur manajerial dalam SMP Negeri 3 Palopo. Dalam melaksanakan penelitian ini pengambilan data dilakukan secara langsung dilapangan maka penulis mengungkapkan data menggunakan teknik observasi, interview, dan dokumentasi.

\section{Observasi}

Observasi ini digunakan untuk mengamati secara langsung tentang keadaan sarana dan prasarana, kegiatan pendidikan, kegiatan keseharian Kepala Sekolah, guru dan siswa, serta data lainnya yang berhubungan dengan penelitian ini.

\section{Kuesioner / Angket}

Angket yang diajukan sifatnya tertutup sehingga responden dapat meberikan jawaban sesuai dengan keadaan yang sebenarnya denag memilih salah satu alternative jawaban yang telah disediakan. Angket penelitian ini terdiri dari 20 item, dan setiap item dilengkapi masingmasing empat pilihan jawaban. Untuk kepentingan analisis data guna memperoleh kesimpulan 
umum mengenai komitmen kepala sekolah maupun berdasarkan indikator komitmen kepala sekolah, maka setiap pilihan jawaban akan diberikan bobot dengan menggunakan skala likert, dengan empat skala.

\section{Dokumentasi}

Data dokumenter yaitu laporan tertulis dari suatu peristiwa yang isinya terdiri dari penjelasan dari pemikiran terhadap peristiwa itu, yaitu berupa arsip-arsip buku-buku yang dimiliki oleh lembaga tersebut. Dokumentasi digunakan untuk mendapatkan: sejarah singkat tentang SMP Negeri 3 Palopo, profil sekolah, visi-misi, struktur organisasi, data tentang guru dan pegawai, data tentang siswa, program dan agenda yang dimiliki SMP Negeri 3 Palopo.

\section{Hasil Penelitian}

\section{Karakteristik Responden}

Identitas responden penelitian yaitu guru SMP Negeri 3 Palopo sebanyak 20 orang, akan disajikan berupa data tentang masa kerja dan tingkat pendidikan.

Tabel 1. Keadaan Guru Berdasarkan Masa Kerja

\begin{tabular}{llrr}
\hline No & Masa kerja & Frekuensi & Persentase \\
\hline 1. & Lebih dari 20 tahun & 10 & 50,00 \\
2. & Antara 10 sampai 20 tahun & 7 & 35,00 \\
3. & Kurang dari 10 tahun & 3 & 15,00 \\
\hline & Jumlah & 20 & 100,00 \\
\hline
\end{tabular}

Tabel di atas menunjukkan bahwa masa kerja guru di SMP Negeri 3 Palopo sebagian besar lebih dari 20 tahun dan kurang dari 10 tahun yang mencapai 5 responden atau 38,50\% disusul masa kerja antara 10 sampai 20 tahun sebanyak 3 responden atau 24,00\%

Tabel 2. Keadaan Guru Berdasarkan Tingkat Pendidikan

\begin{tabular}{llrr}
\hline No & Tingkat Pendidikan & Frekuensi & Persentase \\
\hline 1. & Diploma Dua & 2 & 10,00 \\
2. & Strata Satu & 18 & 90,00 \\
\hline & Jumlah & 20 & 100,00 \\
\hline
\end{tabular}

Tabel diatas menunjukan bahwa tingkat pendidikan tertinggi guru di SMP Negeri 3 Palopo sebagian besar adalah sarjana (S1) yang mencapai 11 responden atau 84,60\%, dan Diploma Dua sebanyak 2 responden atau 15,40\%. Hal ini menunjukkan bahwa guru-guru SMP Negeri 3 Palopo pada umumnya adalah Sarjana (S1).

\section{Persepsi Guru Tentang Perencanaan Kepala Sekolah}

Guru meperoleh gambaran mengenai persepsi guru tentang kemampuan perencanaan kepala sekolah SMP Negeri 3 Palopo, maka berikut ini akan disajikan jawaban responden pada tabel 3 sampai tabel 11.

Tabel 3. Membantu Guru dalam Penyusunan Pembelajaran Sesuai dengan Kurikulum

\begin{tabular}{lrr}
\hline Kategori Jawaban & Frekuensi & Persentase \\
\hline Selalu & 12 & 60,00 \\
Sering & 8 & 40,00 \\
Kadang-kadang & 0 & 0 \\
Tidak pernah & 0 & 0 \\
\hline Jumlah & 20 & 100,00 \\
\hline
\end{tabular}


Tabel 3 menunjukkan bahwa sebagian besar responden menyatakan kepala sekolah selalu membantu guru dalam penyusunan pembelajaran sesuai kurikulum, sebagaimana dinyatakan oleh 12 responden atau $60,00 \%$ dan sisanya sebanyak 8 responden atau 40,00\% menyatakan sering.

Tabel 4. Merencanakan Kegiatan Ekstrakurikuler Siswa Bersama dengan Guru

\begin{tabular}{lrr}
\hline Kategori Jawaban & Frekuensi & Persentase \\
\hline Selalu & 8 & 40,00 \\
Sering & 7 & 35,00 \\
Kadang-kadang & 5 & 25,00 \\
Tidak pernah & 0 & 0 \\
\hline Jumlah & 20 & 100,00 \\
\hline
\end{tabular}

Tabel 4 di atas menunjukkan bahwa sebagian besar responden menyaatakan kepala sekolah selalu bersama dengan guru merencanakan kegiatan ekstrakurikuler siswa, seabagaimana dinyatakan oleh 8 responden atau 40,00 \% disusul 7 responden atau 35,00\% yang menyatakan sering dan sisanya sebanyak 5 responden atau $25,00 \%$ yang menyatakan kadang-kadang.

Tabel 5. Membuat Perencanaan tentang Kebutuhan Guru Setiap Tahun.

\begin{tabular}{lrr}
\hline Kategori Jawaban & Frekuensi & Persentase \\
\hline Selalu & 8 & 40,00 \\
Sering & 7 & 35,00 \\
Kadang-kadang & 5 & 25,00 \\
Tidak pernah & 0 & 0 \\
\hline Jumlah & 20 & 100,00 \\
\hline
\end{tabular}

Tabel 5 di atas menunjukkan bahwa sebagian besar responden menyatakan kepala sekolah selalu membuat perencanaan tentang kebutuhan guru setiap tahunnya, sebagaimana dinyatakan oleh 8 responden atau 40,00 \% disusul pernyataan kadang-kadang sebanyak 5 responden atau $25,00 \%$ dan sering 8 responden atau 40,00 \%.

Tabel 6. Rencana Anggaran Sekolah dalam Periode Tertentu.

\begin{tabular}{lrr}
\hline Kategori Jawaban & Frekuensi & Persentase \\
\hline Selalu & 9 & 45,00 \\
Sering & 7 & 35,00 \\
Kadang-kadang & 4 & 20,00 \\
Tidak pernah & 0 & 0 \\
\hline Jumlah & 20 & 100,00 \\
\hline
\end{tabular}

Tabel 6 di atas menunjukkan bahwa sebagian besar responden menyatakan kepala sekolah selalu membuat besarnya rencana anggaran sekolah dalam periode tertentu, sebagaimana dinyatakan oleh 9 responden atau 45,00 \% disusul 7 responden atau 35,00\% menyatakan sering dan sisanya sebanyak 4 responden atau 30,77\% menyatakan kadang-kadang.

Tabel 7. Membuat Alokasi Rencana Anggaran Pendapatan dan Belanja Sekolah (RAPBS).

\begin{tabular}{lrr}
\hline Kategori Jawaban & Frekuensi & Persentase \\
\hline Selalu & 10 & 50,00 \\
Sering & 7 & 35,00 \\
Kadang-kadang & 3 & 15,00 \\
Tidak pernah & 0 & 0 \\
\hline Jumlah & 20 & 100,00 \\
\hline
\end{tabular}


Tabel 7 menunjukkan bahwa sebagian besar responden menyatakan kepala sekolah selalu membuat Alokasi Rencana Anggaran Pendapatan dan Belanja Sekolah (RAPBS), sebagaimana dinyatakan oleh 10 responden atau $50,00 \%$ disusul 7 responden atau 35,00\% yang menyatakan seringdan sisanya sebanyak 3 responden atau $15,00 \%$ menyatakan kadangkadang.

Tabel 8. Membuat Perencanaan Sumber-sumber Dana Penyelenggaraan Pendidikan

\begin{tabular}{lrr}
\hline Kategori Jawaban & Frekuensi & Persentase \\
\hline Selalu & 10 & 50,00 \\
Sering & 7 & 35,00 \\
Kadang-kadang & 3 & 15,00 \\
Tidak pernah & 0 & 0 \\
\hline Jumlah & 20 & 100,00 \\
\hline
\end{tabular}

Tabel 8 di atas menunjukkan bahwa terdapat 10 responden atau 50,00 \% menyatakan kepala sekolah selalu membuat perencanaan sumber-sumber dana penyelenggaraan pendidikan, disusul pernyataan kadng-kadang sebanyak 3 responden atau $15,00 \%$ dan 7 responden atau $35,00 \%$ menyatakan sering.

Tabel 9. Tidak Menyusun Rencana Kebutuhan Sarana dan Prasarana Sekolah.

\begin{tabular}{lrr}
\hline Kategori Jawaban & Frekuensi & Persentase \\
\hline Selalu & 10 & 50,00 \\
Sering & 0 & 0 \\
Kadang-kadang & 7 & 35,00 \\
Tidak pernah & 3 & 15,00 \\
\hline Jumlah & 20 & 100,00 \\
\hline
\end{tabular}

Tabel 9 di atas menunjukkan sebagian besar responden menyatakan kepala sekolah kadang-kadang tidak menyusun rencana kebutuhan sarana dan prasarana sekolah, sebagaimna dinyatakan oleh 7 responden atau 35,00\% disusul pernyataan selalu sebanyak 10 responden atau $50,00 \%$ dan 3 responden atau $15,00 \%$ menyatakan tidak pernah.

Tabel 10. Menyusun Pengadaan Kebutuhan Sarana dan Prasarana di Sekolah.

\begin{tabular}{lrr}
\hline Kategori Jawaban & Frekuensi & Persentase \\
\hline Selalu & 10 & 50,00 \\
Sering & 3 & 15,00 \\
Kadang-kadang & 4 & 20,00 \\
Tidak pernah & 3 & 15,00 \\
\hline Jumlah & 20 & 100,00 \\
\hline
\end{tabular}

Tabel 10 di atas menunjukkan sebagian besar responden menyatakan kepala sekolah selalu menyusun pengadaan kebutuhan sarana dan prasarana pendidkan di sekolah, sebagaimana dinyatakan oleh 10 responden atau 50,00\% disusul pernyataan sering 3 responden atau 15,00 $\%$ kemudian 4 responden atau 20,00\% menyatakan kadang-kadang dan 3 responden atau $23,08 \%$ yang menyatakan tidak pernah. Hal ini berarti Kepala sekolah selalu menyusun pengadaan kebutuhan sarana dan prasarana pendidikan di sekolah yang memungkinkan proses pembelajaran di sekolah dapat berlangsung optimal demi pencapaian tujuan pendidikan.

Setelah disajikan jawaban responden berdasarkan item-item pertanyaan, maka berikut ini disajikan hasil analisis rata-rata komitmen kepemimpinan kepala sekolah dalam mengimplementasi kebijakan untuk meningkatkan mutu pendidikan di SMP Negeri 3 Palopo. 
Tabel 11. Hasil Analisis Rata-rata komitmen Perencanaan Kepala Sekolah

\begin{tabular}{llll}
\hline Item & $\mathrm{n}$ & $\mathrm{N}$ & $\mathrm{n}: \mathrm{N}$ \\
\hline 1. & 50 & 20 & 3 \\
2. & 50 & 20 & 3 \\
3. & 34 & 20 & 2 \\
4. & 50 & 20 & 3 \\
5. & 50 & 20 & 3 \\
6. & 34 & 20 & 2 \\
7. & 34 & 20 & 2 \\
8. & 34 & 20 & 2 \\
\hline Rata-rata & 42 & 20 & 3 \\
\hline
\end{tabular}

Dari analisis tabel 11 di atas, maka dapat ditarik kesimpulan bahwa komitmen kepala sekolah dalam mengimplementasi kebijakan untuk meningkatkan mutu pendidkan di SMP Negeri 3 Palopo untuk aspek kemampuan perencanaan terutama dalam hal kurikulum, keuangan, kesiswaan, sarana dan prasarana sekolah dengan nilai rata-rata 3 dari 8 item pertanyaan.

\section{Persepsi Guru Tentang Kemampuan Pengorganisasian Kepala Sekolah}

Guna memperoleh gembaran mengenai komitmen kepala sekolah dalam implementasi kebijakan untuk meningkatkan mutu pendidikan di SMP Negeri 3 Palopo, maka berikut ini akan disajikan jawaban responden pada tabel 12 sampai tabel 17.

Tabel 12. Membagi Tugas Mengajar Guru Sesuai dengan Kemampuan.

\begin{tabular}{lrr}
\hline Kategori Jawaban & Frekuensi & Persentase \\
\hline Selalu & 10 & 50,00 \\
Sering & 7 & 35,00 \\
Kadang-kadang & 3 & 15,00 \\
Tidak pernah & 0 & 0,00 \\
\hline Jumlah & 20 & 100,00 \\
\hline
\end{tabular}

Tabel 12 di atas menunjukkan bahwa sebagian besar responden menyatakan kepala sekolah selalu membagi tugas-tugas mengajar guru sesuai dengan kemampuan guru, sebagaimana dinyatakan oleh 10 responden atau 50,00 \%, pernyataan kadang-kadang sebanyak 3 responden atau $15,00 \%$ dan pernyataan sering 7 responden atau 35,00 \%.

Tabel 13. Menyusun Tugas Guru Selain Mengajar (Mis. Pencatatan Daftar Inventaris Sekolah).

\begin{tabular}{lrr}
\hline Kategori Jawaban & Frekuensi & Persentase \\
\hline Selalu & 11 & 55,00 \\
Sering & 0 & 0,00 \\
Kadang-kadang & 9 & 45,00 \\
Tidak pernah & 0 & 0,00 \\
\hline Jumlah & 20 & 100,00 \\
\hline
\end{tabular}

Tabel 13 di atas menunjukkan bahwa sebagian besar responden menyatakan kepala sekolah selalu menyusun tugas-tugas guru selain tugas mengajar seperti pencatatan daftar inventaris sekolah yang ada dikelas masing-masing, sebagaimana dinyatakan oleh 11 responden atau $55,00 \%$ dan sisanya sebanyak 9 responden atau 45,00 \% menyatakan kadang-kadang. 
Tabel 14. Menjelaskan Mekanisme Pelaksanaan Tugas Mengajar Guru.

\begin{tabular}{lrr}
\hline Kategori Jawaban & Frekuensi & Persentase \\
\hline Selalu & 3 & 15,00 \\
Sering & 17 & 85,00 \\
Kadang-kadang & 0 & 0,00 \\
Tidak pernah & 0 & 0,00 \\
\hline Jumlah & 20 & 100,00 \\
\hline
\end{tabular}

Tabel 14 di atas menunjukkan bahwa terdapat 17 responden atau 85,00\% menyatakan kepala sekolah sering menjelaskan mekanisme pelaksanaan tugas mengajar guru dan pernyataan selalu sebanyak 3 responden atau $15,00 \%$.

Tabel 15. Mengkoordinasikan Pelaksanaan Tugas Guru Di Luar Tugas Mengajar.

\begin{tabular}{lrr}
\hline Kategori Jawaban & Frekuensi & Persentase \\
\hline Selalu & 10 & 50,00 \\
Sering & 0 & 0,00 \\
Kadang-kadang & 10 & 50,00 \\
Tidak pernah & 0 & 0,00 \\
\hline Jumlah & 20 & 100,00 \\
\hline
\end{tabular}

Tabel 15 di atas menunjukkan bahwa sebagian besar responden menyatakan kepala sekolah sering mengkoordinasikan pelaksanaan tugas guru di sekolah dan luar tugas mengajar, sebagaimana dinyatakan oleh 10 responden atau 50,00 \% dan sisanya sebanyak 10 responden atau $50,00 \%$ menyatakan kadang-kadang.

Tabel 16. Mengalokasikan Sarana dan Prasarana Pendidikan Sesuai Kebutuhan Mengajar Guru.

\begin{tabular}{lrr}
\hline Kategori Jawaban & Frekuensi & Persentase \\
\hline Selalu & 9 & 45,00 \\
Sering & 0 & 0,00 \\
Kadang-kadang & 11 & 55,00 \\
Tidak pernah & 0 & 0,00 \\
\hline Jumlah & 20 & 100,00 \\
\hline
\end{tabular}

Tabel 16 di atas menunjukkan bahwa terdapat 9 responden atau 45,00 \% menyatakan kepala sekolah selalu mengalokasikan sarana dan prasarana pendidkan sesuai kebutuhan mengajar guru dan hanya 11 responden atau 55,00 \% menyatakan kadang-kadang.

Setelah disajikan jawaban responden berdasarkan item pertanyaan, maka berikut ini disajikan hasil analisis rata-rata komitmen kepala sekolah dalam mengimplementasi kebijakan untuk meningkatkan mutu pendidikan di SMP Negeri 3 Palopo.

Tabel 17. Kemampuan Pengorganisasian Kepala Sekolah

\begin{tabular}{llll}
\hline Item & $\mathrm{n}$ & $\mathrm{N}$ & $\mathrm{n}: \mathrm{N}$ \\
\hline 9. & 34 & 20 & 2 \\
10. & 50 & 20 & 3 \\
11. & 50 & 20 & 3 \\
12. & 50 & 20 & 3 \\
13. & 50 & 20 & 3 \\
\hline Rata-rata & 46 & 20 & 2 \\
\hline
\end{tabular}

Dari analisis tabel 17 di atas, maka dapat ditarik kesimpulan bahwa komitmen kepala sekolah dalam mengimplementasi kebijakan untuk meningkat mutu pendidikan di SMP Negeri 3 Palopo untuk aspek kemampuan pengorganisasikan mencapai rata-rata 4 dari 5 item pertanyaan. 


\section{Persepsi Guru Tentang Kemampuan Supervisi Kepala Sekolah}

Guna memperoleh gambaran mengenai komitmen kepala sekolah dalam mengimplementasi kebijakan untuk meningkatkan mutu pendidikan di SMP Negeri 3 Palopo, maka berikut ini disajikan jawaban responden pada tabel 18 sampai tabel 23.

Tabel 18. Memantau Dan Mengevaluasi Pelaksanaan Kegiatan Belajar Mengajar Di Sekolah

\begin{tabular}{lrr}
\hline Kategori Jawaban & Frekuensi & Persentase \\
\hline Selalu & 8 & 40,00 \\
Sering & 10 & 50,00 \\
Kadang-kadang & 2 & 10,00 \\
Tidak pernah & 0 & 0,00 \\
\hline Jumlah & 20 & 100,00 \\
\hline
\end{tabular}

Tabel 18 di atas menunjukkan sebagian besar responden menyatakan kepala sekolah sering memantau dan mengevaluasi pelaksanaan kegiatan belajar mengajar di sekolah, sebagaimana dinyatakan oleh 10 responden atau $50,00 \%$, pernyataan selalu sebanyak 8 responden atau $40,00 \%$ dan kadang-kadang sebanyak 2 responden atau 10,00\%.

Tabel 19. Memperhatikan Keadaan Perangkat Pembelajaran Guru Yang Digunakan.

\begin{tabular}{lrr}
\hline Kategori Jawaban & Frekuensi & Persentase \\
\hline Selalu & 8 & 40,00 \\
Sering & 0 & 0,00 \\
Kadang-kadang & 7 & 35,00 \\
Tidak pernah & 5 & 25,00 \\
\hline Jumlah & 20 & 100,00 \\
\hline
\end{tabular}

Tabel 19 di atas menunjukkan bahwa terdapat 10 responden atau 50,00 \% menyatakan kepala sekolah selalu memperhatikan keadaan perangkat pembelajaran guru yang digunakan, pernyataan kadang-kadang sebanyak 5 responden atau 25,00 \% dan 5 responden atau 25,00 $\%$ menyatakan tidak pernah.

Tabel 20. Melaksanakan Supervise Kelas Sesuai Dengan Program Sekolah.

\begin{tabular}{lrr}
\hline Kategori Jawaban & Frekuensi & Persentase \\
\hline Selalu & 10 & 50,00 \\
Sering & 7 & 35,00 \\
Kadang-kadang & 3 & 15,00 \\
Tidak pernah & 0 & 0,00 \\
\hline Jumlah & 20 & 100,00 \\
\hline
\end{tabular}

Tabel 20 di atas menunjukkan bahwa sebagian besar responden menyatakan kepala sekolah selalu melaksanakan supervisi kelas sesuai dengan program sekolah, sebagaimana dinyatakan oleh 10 responden atau $50,00 \%$ dan sering sebagaimana dinyatakan oleh 7 responden atau $35,00 \%$, sisanya sebanyak 3 responden atau 15,00\% mengatakan kadang-kadang.

Tabel 21. Melaksanakan Pertemuan Dengan Guru Untuk Membahas Masalah di Sekolah.

\begin{tabular}{lrr}
\hline Kategori Jawaban & Frekuensi & Persentase \\
\hline Selalu & 9 & 45,00 \\
Sering & 8 & 40,00 \\
Kadang-kadang & 3 & 15,00 \\
Tidak pernah & 0 & 0,00 \\
\hline Jumlah & 20 & 100,00 \\
\hline
\end{tabular}

Tabel 21 di atas menunjukkan bahwa terdapat 9 responden atau 45,00 \% menyatakan kepala sekolah secara periodik selalu melaksanakan pertemuan dengan guru untuk membahas 
masalah-masalah di sekolah, disusl pernyataan sering sebanyak 8 responden atau 40,00\% dan 3 responden atau 15,00\% menyatakan kadang-kadang.

Tabel 22. Mengawasi Pelaksanaan Tugas Mengajar Guru.

\begin{tabular}{lrr}
\hline Kategori Jawaban & Frekuensi & Persentase \\
\hline Selalu & 10 & 50,00 \\
Sering & 8 & 40,00 \\
Kadang-kadang & 2 & 10,00 \\
Tidak pernah & 0 & 0,00 \\
\hline Jumlah & 20 & 100,00 \\
\hline
\end{tabular}

Tabel 22 di atas menunjukkan bahwa sebagian besar responden menyatakan kepala sekolah selalu mengawasi pelaksanaan tugas mengajar guru sebagaiman dinyatakan oleh 10 responden atau 50,00 \% disusul 2 responden atau 10,00 \% menyataka kadang-kadang dan 8 responden atau $40,00 \%$ yang menyatakan sering.

Setelah disajikan jawaban responden berdasarkan item pertanyaan, maka berikut ini disajikan hasil analisis Rata-rata komitmen kepala sekolah dalam mengimplementasi kebijakan untuk meningkatkan mutu pendidikan di SMP Negeri 3 Palopo.

Tabel 23. Kemampuan Supervisi Kepala Sekolah

\begin{tabular}{llll}
\hline Item & $\mathrm{n}$ & $\mathrm{N}$ & $\mathrm{n}: \mathrm{N}$ \\
\hline 14. & 34 & 20 & 2 \\
15. & 34 & 20 & 2 \\
16. & 50 & 20 & 3 \\
17. & 34 & 20 & 2 \\
18. & 34 & 20 & 2 \\
\hline Rata-rata & 37 & 20 & 2 \\
\hline
\end{tabular}

Dari analisis tabel 23 di atas, maka dapat ditarik kesimpulan bahawa komitmen kepemimpinan kepala sekolah tentang kemampuan manajerial untuk aspek kemampuan supervise mencapai rata-rata 3 dari 5 pertanyaan.

\section{Persepsi Guru Tentang Kemampuan Pengawasan Kepala Sekolah}

Guru memperoleh gambaran mengenai komitmen kepla sekolah dalam mengimplementasi kebijakan untuk meningkatkan mutu pendidikan di SMP Negeri 3 Palopo, maka berikut ini akan disajikan jawaban responden pada tabel 24. sampai tabel 27.

Tabel 24. Mengawasi Pelaksanaan Program Semesteran dan Tahunan Sekolah.

\begin{tabular}{lrr}
\hline Kategori Jawaban & Frekuensi & Persentase \\
\hline Selalu & 12 & 60,00 \\
Sering & 8 & 40,00 \\
Kadang-kadang & 0 & 0,00 \\
Tidak pernah & 0 & 0,00 \\
\hline Jumlah & 20 & 100,00 \\
\hline
\end{tabular}

Tabel 24 di atas menunjukkan bahwa sebagian besar responden menyatakan kepala sekolah selalu mengawasi pelaksanaan program smesteran dan tahunan sekolah yang mencapai 12 responden atau $60,00 \%$ dan sisanya sebanyak 8 responden atau 40,00 \% yang menyatakan sering. 
Tabel 25. Mengadakan Pembinaan Bagi Guru Yang Sering Melalaikan Tugas

\begin{tabular}{lrr}
\hline Kategori Jawaban & Frekuensi & Persentase \\
\hline Selalu & 12 & 60,00 \\
Sering & 8 & 40,00 \\
Kadang-kadang & 0 & 0,00 \\
Tidak pernah & 0 & 0,00 \\
\hline Jumlah & 20 & 100,00 \\
\hline
\end{tabular}

Tabel 25 di atas menunjukkan bahwa sebagian besar responden menyatakan kepala sekolah selalu mengadakan pembinaan bagi guru yang sering melalaikan tugas, sebagaimana dinyatakan oleh 12 responden atau $60,00 \%$ dan sisanya sebanyak 8 responden atau 40,00 \% menyatakan sering.

Setelah disajikan jawaban berdasarkan item pertanyaan, maka berikut ini disajikan hasil analisis rata-rata komitmen kepala sekolah dalam mengimplementasi kebijakan untuk meningkatkan mutu pendidikan di SMP Negeri 3 Palopo.

Tabel 26. Rata-Rata Persepsi Guru Tentang Pengawasan Kepala Sekolah

\begin{tabular}{llll}
\hline Item & $\mathrm{n}$ & $\mathrm{N}$ & $\mathrm{n}: \mathrm{N}$ \\
\hline 19. & 50 & 20 & 4 \\
20. & 50 & 20 & 4 \\
\hline Rata-rata & 46 & 20 & 4 \\
\hline
\end{tabular}

Dari analisis tabel di atas maka dapat ditarik kesimpulan bahwa komitmen kepala sekolah untuk aspek pengawasan dalam mengimplementasi kebijakan untuk meningkatkan mutu pendidikan di SMP Negeri 3 Palopo sering dilakukan oleh kepala sekolah terhadap guru untuk perbaikan ke depannya.

Setelah disajikan hasil analisis komitmen kepala sekolah dalam mengimplementasi kebijakan untubk meningkatkan mutu pendidkan berdasarkan indikator, selanjutnya disajikan hasil analisis keseluruhan jawaban responden (20 item), untuk lebih jelasnya dapat dilihat pada tabel berikut :

Tabel 27. Hasil Analisis Rata-Rata Untuk Komitmen Kepala Sekolah

\begin{tabular}{rrrr}
\hline Item & Rata-rata $\mathrm{n}$ & $\mathrm{N}$ & $\mathrm{n}: \mathrm{N}$ \\
\hline $1-8$ & 42 & 20 & 3 \\
$9-13$ & 46 & 20 & 4 \\
$14-18$ & 37 & 20 & 3 \\
$19-20$ & 50 & 20 & 4 \\
\hline Rata-rata & 50 & 20 & 4 \\
\hline
\end{tabular}

Berdasarkan analisis tabel 27 di atas, maka untuk setiap indikator atau aspek maupun rekapitulasi dari pernyataan responden mengenai komitmen kepala sekolah menunjukkan bahwa baik berdasarkan indikator atau aspek maupun rekapitulasi dari pernyataan responden memberikan gambaran komitmen kepala sekolah dalam mengimplementasi kebijakan dalam meningktakan mutu pendidkan di SMP Negeri 3 Palopo termasuk dalam kategori selalu yang berarti bahwa kepala sekolah selalu menunjukkan kemampuan atau komitmennya dilingkup sekolah yang dipimpinnya.

\section{Pembahasan}

Hasil penelitian menunjukkan bahwa komitmen kepala sekolah dalam mengimplementasi kebijakan untuk meningktakan mutu pendidikan di SMP Negeri 3 Palopo dalam kategori selalu. $\mathrm{Hal}$ ini mengidentifikasi bahwa kepala sekolah telah mampu melaksanakan berbagai kempuan 
menejerial sehingga dapat melakukan perencanaan, pengorganisasian, supervisi, dan pengawasan dengan baik demi kemajuan pendidkan.

Komitmen kepala sekolah dalam mengimplementasi kebijakan untuk meningkatkan mutu pendidkan di SMP Negeri 3 Palopo dengan berdasarkkan penilaian guru-guru selaku bawahan kepala sekolah hendaknya merupakan suatun penilaian atau tanggapan yang objektif, mengingat guru-guru merupakan bawahan kepala sekolah dimana guru-guru dalam sehariharinya harus bertanggung jawab kepada kepala sekolah sehingga mengetahui betul tentang komitmne kepala sekolah.

Aspek yang dinilai dalam penilaian komitmen kepala sekolah di SMP Negeri 3 Palopo dapat mencakup tiga dimensi yakni: (a) komitmen terhadap tugas, (b) pelaksanaan tugas, dan (c) hasil kerja. Komitmen terhadap tugas sebagai aktualisasi dari kompetensi kepribadian dan kompetensi sosial kepala sekolah. Pelaksanaan tupoksi sebagai aktualiasi dari kompetensi manajerial, kompetensi supervisi dan kompetensi kewirausahaan yang dimiliki kepala sekolah Sedangkan hasil kerja merupakan dampak dari pelaksanaan tugas pokok kepala sekolah sebagai refleksi dari semua dimensi kompetensi kepala sekolah.

Berkenaan dengan tugas pokok kepala sekolah ini, pada semua jenjang pendidikan tugas kepala sekolah akan mencakup tiga bidang, yaitu: (a) tugas manajerial, (b) supervisi dan (c) kewirausahaan. Penilaian kinerja kepala sekolah bertujuan untuk:

1. Memperoleh data tentang pelaksanaan tugas pokok, fungsi dan tanggung jawab kepala sekolah dalam melaksanakan fungsi-fungsi manajerial dan supervisi/pengawasan pada sekolah yang dipimpinnya.

2. Memperoleh data hasil pelaksanaan tugas dan tanggung jawabnya sebagai peminpin sekolah.

3. Menentukan kualitas kerja kepala sekolah sebagai dasar dalam promosi dan penghargaan yang diberikan kepadanya.

4. Menentukan program peningkatan kemampuan profesional kepala sekolah dalam konteks peningkatan mutu pendidikan pada sekolah yang dipimpinnya.

5. Menentukan program umpan balik bagi peningkatan dan pengembangan diri dan karyanya dalam konteks pengembangan karir dan profesinya.

Hasil penelitian dan pendapat di atas menunjukkan bahwa kepala sekolah yang memiliki kemampuan yang sanagt kompleks berkaitan dengan komitmen kepala sekolah, meliputi tanggung jawab dalam perencanaan sekolah, pengorganisasian, supervisi, dan pengawasan terhadap seluruh proses di sekolah. Sebagai manajer, kepala sekolah mempunyai kekuasaan atau wewenang untuk mengarahkan semua komponen sekolah sesuai dengan tugas dan tanggung jawabnya. Oleh karena itu, setiap kepala sekolah dituntut secara professional dalam melaksanakan tugasnya dengan baik mengingat kepala sekolah merupakan perencana, yang mengorganisasikan seluruh sumber daya di sekoah dan yang melakukan supervisi dan pengawasan seluruh program pendidikan di sekolah demi kemajuan pendidikan.

\section{Kesimpulan}

Berdasarkan hasil penelitian mengenai komitmne kepala sekolah dalam mengimplementasi kebijakan untuk meningkatrkan mutu pendidkan di SMP Negeri 3 Palopo disimpulkan bahwa secara umum komitmen kepala sekolah, sedangkan berdasarkan indikator atau aspek komitmen kepala sekolah yaitu: 
1. Komitmen Kepemimpinan Kepala Sekolah sebagai perencana dalam hal keuangan dan sarana sekolah selalu dilaksanakan tetapi dalam hal kesiswaan menurut guru masih kurang dalam pelaksanaanya.

2. Komitmen Kepemimpinan dalam kemampuan manajerial sebagai pengorganisasian selalu melaksanakan tugasnya

3. Komitmen Kepemimpinan Kepala Sekolah dalam supervisi selalau melaksanakan tugasnya

4. Komitmen Kepemimpinan Kepala Sekolah dalam hal ini sebagai pengawas selalu dilaksanakan.

Mengacu kepada kesimpulan penelitian di atas, maka disarankan kepada :

1. Kepala Sekolah, hendaknya lebih meningkatkan pelaksaan perencanaan terutama dalam hal kesiswaan.

2. Kepala Sekolah dalam hal pengawasan harus mengawasi pelaksanaan tugas mengajar guru.

3. Kepala Sekolah lebih meningkatkan pelaksanaan supervise terhadap guru.

4. Kepala Sekolah harus melaksanakan tugasnya sebagai pengorganisasian.

\section{Referensi}

Arismunandar. (2001). Manajemen Berbasis Sekolah. Jakarta: PT. Rosdakarya

Bishop, Scott \& Burroughs. (2000). Support Commitment and Employee Outcomes in a Team Environment. Journal of Management, 26(6).

Denim, S. (2002). Inovasi Pendidkan. Bandung: Pustaka Setia

Daryanto, M 2005. Administrasi Pendidkan. Jakarta: PT. Rineka Cipta

Kinicki, A. \& Kreitner, R. (2008). Organizational Behavior: Key Concepts, Skills and Best Practices. New York: McGraw-Hill.

Scott, R. W. \& Gerald F. D. (2007). Organizations and Organizing. New Jersey: Pearson Education.

Sobry S. M. (2012). Manajemen Pendidikan. Lombok: Holistica

Sugiyono. (2011). Penelitian Pendidikan. Bandung: Alfabeta 